\title{
The use of expert review in component development for customer satisfaction towards E-hailing
}

\author{
Nur Athirah Nabila Mohd Idros, Hazura Mohamed, Ruzzakiah Jenal
}

Faculty of Information Science and Technology, Universiti Kebangsaan Malaysia, Malaysia

\begin{abstract}
Article Info
Article history:

Received Feb 14, 2019

Revised Jul 5, 2019

Accepted Jul 25, 2019

\section{Keywords:}

Customer satisfaction model

DART model

Online transportation service

Service science

Value Co-creation

ABSTRACT

The emergence of e-hailing apps has increased the demand of customers because online transportation service is very convenient in this modern society. As e-hailing provides an online platform for booking a ride, this apps also functions to connect the customer and driver, while at the same time allowing the customers to interact with customer service that company has provided to keep track of the satisfaction. Competition among e-hailing companies has increased since customers nowadays are very influential and knowledgeable in terms of choosing any transportation services that they want. The purpose of this study is to identify customer satisfaction towards ehailing by embedding value co-creation model. Value co-creation is one of the concepts in Service Science that has been proved to increase customer satisfaction. Value co-creation is focused on company-customer interaction that helps in maintaining a good customer relationship and improve the company's performance. Expert identification and evaluation procedure are used as a technique to adapt the definition of value co-creation model towards e-hailing. Then, the other factor from previous studies will be proposed as a component to be listed under value co-creation model and reviewed by an expert.
\end{abstract}

Copyright @ 2020 Institute of Advanced Engineering and Science. All rights reserved.

Corresponding Author:

Nur Athirah Nabila Mohd Idros, Faculty of Information Science and Technology, Universiti Kebangsaan Malaysia, 43600 Bangi, Selangor, Malaysia.

Email: athirahnabila.idros@gmail.com

\section{INTRODUCTION}

E-hailing is an online transportation service that experiencing fast growth and has brought a revolution into the transportation industry since the establishing of Uber in 2009 and Lyft in 2012 [1]. E-hailing with other names also known as ride-hailing, ride-booking or on-demand ride deliver the same purpose in connecting the customer's location to the driver via global positioning system (GPS) and the fare will be charged based on distance [2]. E-hailing has rapidly received popularity among customers since the number of people using the internet is growing especially in the era of digital services [3].

The emergence of e-hailing, however, has result in competitive advantage between e-hailing companies to attract a huge number of registered customers because, at the present time, e-hailing monitors the satisfaction only towards the driver by allowing the customers to evaluate the travel experience on a scale of 1 to 5 stars [4]. Consequently, e-hailing companies need a method to identify customer satisfaction in terms of technology provided. In order to win the customers' hearts, a system should be well designed and has a communication channel for an interaction function between company and customers [5].

Nowadays, customers are well-informed about products or services that they want to choose which lead the companies to use the trend of value co-creation by actively involving the customers to create a value during the process of service development [6]. Value co-creation is one of the concepts in Service Science that involves interactions and activities among companies, customers and other associated actors to 
encourage customer participation in co-creation activities which also will lead to increase customer satisfaction and loyalty [7].

It should be noted that value co-creation helps to increase customer satisfaction and for that reason, e-hailing companies need to adopt value co-creation concept for continuous improvement especially when providing the system. Hence, to highlight the issues, e-hailing satisfaction factors will be proposed by using value co-creation model and the definition of the factor will be adapted for e-hailing. Next, this paper will also propose a matched component to be listed under value co-creation model and go through the expert review process.

The contributions of this paper are organized as follows. Firstly, the paper will describe the related works regarding e-hailing, value co-creation, and expert review. Secondly, there will be an explanation of the expert identification and evaluation procedure in the research method section. Then, for result and discussion, the expert will justify the adaption definition of value co-creation model and the matched component. Finally, a customer satisfaction model towards e-hailing will be designed based on a result of the expert review.

\section{RELATED WORKS}

This section explained the related works on e-hailing and value co-creation. After that, the description of the expert review will be featured in this study. Below are the explanations to support the research work.

\subsection{E-hailing}

E-hailing offers an innovative ride-booking service to ensure the system that connects the drivers and customers is flexible, has easy access and performing consistently well [8]. With e-hailing apps, customers are able to retrieve information regarding vehicle and drivers especially driver's rating, estimated time of arrival, approximate travel fare based on the distance of the route, and can keep an eye to the map for confirming whether the driver used the most favourable travel route [3].

After completing the trip, e-hailing allowed the customers to rate their experience towards the driver by using a scale of 1 to 5 stars, then, the system will calculate the average star rating automatically and driver's star rating will be displayed as one of the driver's information because e-hailing companies use this technique to maintain the quality of services to keep track of customer's satisfaction [4]. E-hailing companies must have strategies to satisfy the customer needs because when customers are satisfied, companies will have a profitable business that will lead to the growth of the economy and contributing positive impact in the transportation industry.

Having a knowledge about e-hailing gave an impact on overall satisfaction because customers will be comfortable to use the system once they understand the overall functions of e-hailing and when they satisfied, it will lead to strengthening e-hailing in the future [1]. Measuring customer satisfaction is a need for companies to develop effective strategies, improve their services and gain a competitive advantage [9].

Previously, there were three customer satisfaction models such as SERVQUAL model, a quality model for e-service and service quality model for online transportation service have been applied for ehailing satisfaction and this paper is a continuation study for e-hailing and value co-creation [10]. SERVQUAL model described service quality which is suitable for this research because e-hailing provides transportation service as the main service [11]. Meanwhile, the quality model for e-service is used because ehailing itself providing transportation service electronically [12]. Then, the service quality model for online transportation service is applied in this research because the model relates the most with e-hailing studies [13].

\subsection{Value co-creation}

Value co-creation is a joint interaction between company and customers that allowing the customers to create value by contributing an idea for the services, then, the company will utilize customer's ideas as knowledge for service innovation [14]. Companies must increase the effectiveness of communication through value co-creation activities to maintain the company-customer relationship for long-term benefits [15].

Customers are considered as a proactive value co-creators because customer involvement towards system provided is important, for instance, when customers giving feedback regarding technological issues, the feedback will represent their opinion and satisfaction towards the company as a whole [16]. Value cocreation is produced when the system provided meets the customer's needs [17].

In the transportation industry, value co-creation is implemented among public transport companies for example, they will give a rewards like discount for travel to customer who is actively co-create the value because customers are responsible for giving out any information that related to transportation services while 
the company will take charge by listening to customer's opinion and provide better services to improve customers experiences [18]. Successful technological and innovative ideas come from customer involvement.

DART model is one of the models in value co-creation that is made up of four factors such as dialogue, access, risk assessment and transparency [19]. The definition of DART model will be explained more in the result and discussion section.

In this paper, four factors of DART model will be used as the main factors of e-hailing satisfaction and then, the definitions will be adapted towards e-hailing. DART model is used as the main factor because all the factors supported strategic interaction between company and customer in terms of service provided [20].

According to [21], it is proven that DART model gives significant influence on customers' positive experience and customer satisfaction. DART model for e-hailing satisfaction will be focused on the readiness of e-hailing company to engage with the customer by referring to customers' personal experiences.

\subsection{Expert Review}

Expert is defined as a person who is able to give professional and useful evaluation based on their knowledge, experience and respected in their field of expertise [22]. The expert must have relevant knowledge, received proper training, well educated, specialized in a certain area, have many experiences and already undergone publication [23].

According to the academic perspective, knowledge from the expert is a valuable source of information and could be used for empirical data by translating the expert's opinion to evaluate the outcome [24]. Opinion from the expert is required to assess and evaluate different terms, techniques, conclusions or implications because the results can be obtained through the decision making approaches and relevant based on expert's knowledge [25].

Expert review is implemented in various ways especially for validating new models or factors. Based on the previous study, factors validation could be obtained from confirmation and involvement of expert to check the accuracy and completeness of all factors including data and technique used then, as expected, the result must meet all validation standard and in line with the research objective [26]. Expert plays an important role in this paper because the validation process will go through expert review. Next section will provide further explanation about the research method that can be used for expert review.

\section{RESEARCH METHOD}

Essentially, this paper will follow the method that consists of two steps which were expert identification and evaluation procedure [30]. The process of expert identification and evaluation procedure are shown in Figure 1.

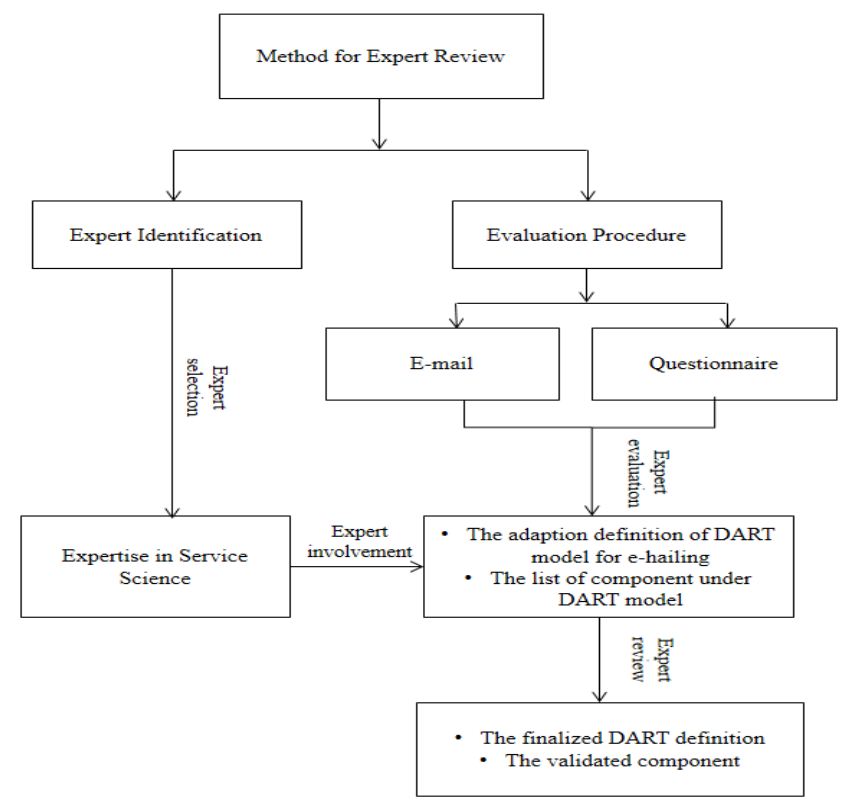

Figure 1. Method for Expert Review 


\subsection{Expert Identification}

Expert identification started with identifying the experts and the selection process are based on an individual's expertise in a related study [27]. Three experts were involved in this evaluation process where two of them are an academician from Malaysia's public university (Institution A) while the other expert is an executive from Malaysia's public sector. All the experts were selected based on their expertise in Service Science since value co-creation is one of the concepts in Service Science field.

The minimum number of expert review range from two to three experts and the experts are required to have at least a master's degree in related field or have at least 2 years of working experience in the research organization [28]. The identification of the experts are as described in Table 1.

Table 1. Expert Identification

\begin{tabular}{ccccc}
\hline Expert & Academic qualification & Experience related & Current position & Experience (Years) \\
\hline 1 & $\mathrm{PhD}$ & Head of Service Science Research & Associate Professor in & 30 years \\
& & Group & Institution A & Senior Lecturer in \\
Institution A & 6 years \\
3 & Master Degree & Member of Service Science & Research Group \\
& Researcher for Service Science and & ICT Expert in & 14 years \\
\hline
\end{tabular}

\subsection{Evaluation Procedure}

During the evaluation process, the experts were given an invitation email for expert review. Then, the official appointment letter was sent by e-mail after they confirmed their involvement in the expert review. A set of questionnaire that proposed the existing customer satisfaction models [11-13] to be listed as the component under DART model was designed. The questionnaire is used as the main instrument for expert evaluation.

The objectives were made clear to the experts. The experts were informed to analyse the relevance of adaption definition of DART model for e-hailing by filling up their review in the space provided. Then, experts are required to evaluate the proposed matched component to be listed under DART model based on 5 Likert scales which referred to [29]. The scale started from 1-strongly disagree to 5-strongly agree.

Furthermore, experts also allowed to give a related comment about the definition of the proposed matched component. It took about five weeks to complete the expert review process. All the proposed components are validated through the expert review. After that, [30] suggested that mean approach can be used as one of a method to measure expert review. Therefore, a Likert scale analysis designed by [31] is used and the mean interpretation for the matched component also being modified to make it compatible with this research work. Table 2 shows the Likert scale with mean interpretation.

Table 2. Likert Scale with Mean Interpretation

\begin{tabular}{lll}
\hline \multicolumn{1}{c}{ Mean Score } & \multicolumn{1}{c}{ Level of Agreement } & \multicolumn{1}{c}{ Mean Interpretation for Matched Component } \\
\hline 1.00 to 2.40 & Disagree & Not compatible \\
2.41 to 3.80 & Partially Agree & Moderately compatible \\
3.81 to 5.00 & Agree & Compatible \\
\hline
\end{tabular}

After obtaining the scales from experts, the mean score is used as the calculation method to interpret the level of experts' agreement. As a result of the level of agreement, the matched component will be interpreted as not compatible, moderately compatible or compatible to be listed under DART model.

\section{RESULTS AND ANALYSIS}

DART model that has been adapted for any research work should be explored and justified through expert review. In the previous study, the expert plays an important role to ensure the four factors in DART model that has been adapted with research work are acceptable and have a practical value in service innovation [32]. This paper used the definition of DART model by [19], then, the definitions are elaborated to adapt for e-hailing context.

Before the expert review, the adaption definition of dialogue was an interaction between company and customer that happened to resolve e-hailing matters by using multiple communication methods. Access is defined as the e-hailing company will provides suitable information and interactive site for the customer to access, order and booking the vehicle in the easiest way. 
Risk assessment is described as the customer will be notified about potential risks of e-hailing which will help the customer to deal and understand ways to avoid risk from happening. Transparency mentioned about trust that has been established between company and customer which involved customers' beliefs that e-hailing company will provide a secure platform and detailed information. After that, the experts commented on the definition given to ensure the adaption definitions of DART model for e-hailing are acceptable. Then, the proposed definitions are adjusted and finalized based on comments from the experts. The definitions are shown in Table 3.

Table 3. Definition of DART Model that has been Adapted for E-hailing through Expert Review

\begin{tabular}{|c|c|c|c|c|}
\hline Factor & Expert 1 & Expert 2 & Expert 3 & Finalized Definition \\
\hline Dialogue & $\begin{array}{l}\text { Customers must be } \\
\text { able to } \\
\text { communicate with } \\
\text { e-hailing company } \\
\text { as dialogue is two- } \\
\text { way } \\
\text { communication. }\end{array}$ & $\begin{array}{l}\text { The interaction that } \\
\text { occurred between e- } \\
\text { hailing company and } \\
\text { customer is to } \\
\text { understand } \\
\text { customers' specific } \\
\text { needs. }\end{array}$ & $\begin{array}{l}\text { Various communication } \\
\text { channels in e-hailing } \\
\text { must be provided to } \\
\text { maintain the company- } \\
\text { customer relationship. }\end{array}$ & $\begin{array}{l}\text { Two-way communication and } \\
\text { interaction that occurred between the } \\
\text { company and e-hailing customer to } \\
\text { understand customer's emotions, } \\
\text { experiences, issues and solve e- } \\
\text { hailing matters together using } \\
\text { various method of communications. }\end{array}$ \\
\hline Access & $\begin{array}{l}\text { The author needs to } \\
\text { mention the various } \\
\text { type of platform } \\
\text { provided for e- } \\
\text { hailing. }\end{array}$ & $\begin{array}{l}\text { E-hailing platform } \\
\text { either website or apps } \\
\text { must be accessible. }\end{array}$ & $\begin{array}{l}\text { Information displayed in } \\
\text { e-hailing need to be } \\
\text { appropriate and easy to } \\
\text { retrieve. }\end{array}$ & $\begin{array}{l}\text { The company displays useful } \\
\text { information by providing an } \\
\text { accessible interactive website or apps } \\
\text { as a platform for e-hailing customers } \\
\text { to access information and service in } \\
\text { the easiest way. }\end{array}$ \\
\hline $\begin{array}{l}\text { Risk } \\
\text { assessment }\end{array}$ & $\begin{array}{l}\text { The author needs to } \\
\text { highlight the } \\
\text { strategies to } \\
\text { mitigate risk in e- } \\
\text { hailing. }\end{array}$ & $\begin{array}{l}\text { The author needs to } \\
\text { ensure that e-hailing } \\
\text { customer aware about } \\
\text { potential risks before, } \\
\text { during, and after } \\
\text { using e-hailing. }\end{array}$ & $\begin{array}{l}\text { The author should add } \\
\text { innovation concept that } \\
\text { has been designed to } \\
\text { reduce the potential risks } \\
\text { in e-hailing. }\end{array}$ & $\begin{array}{l}\text { The company will notify e-hailing } \\
\text { customers about the potential risks } \\
\text { before, during, and after using e- } \\
\text { hailing and customers must be well } \\
\text { prepared to deal and bear the risk if } \\
\text { they want to continue using e- } \\
\text { hailing. }\end{array}$ \\
\hline Transparency & $\begin{array}{l}\text { E-hailing company } \\
\text { must plan the } \\
\text { strategies to obtain } \\
\text { customers' trust. }\end{array}$ & $\begin{array}{l}\text { The author should } \\
\text { mention the } \\
\text { technique that e- } \\
\text { hailing company } \\
\text { used to have } \\
\text { customers' faith. }\end{array}$ & $\begin{array}{l}\text { E-hailing company must } \\
\text { deliver trustworthy } \\
\text { services. }\end{array}$ & $\begin{array}{l}\text { Trust that has been established } \\
\text { between customer and e-hailing } \\
\text { company to protect customer's data } \\
\text { privacy and ensure that the company } \\
\text { will deliver trusted information. }\end{array}$ \\
\hline
\end{tabular}

After adaption definition of DART model towards e-hailing has been justified by the experts, this paper also aimed to well-matched the components to be listed under DART model. The components are matched based on the compatibility of the definitions. DART model is chosen as the main factor because the four factors in DART model convey wide definitions and suitable to be matched with other factors. The proposed components that have been matched to be listed under DART model are shown in Table 4.

Based on Table 4, component such as empathy, personalization, responsiveness, communication, contact, interactivity, tangible, ease of use, website design, information, content adequacy, system availability, accessibility, perceived risk, perceived cognitive, assurance, trust, reliability, security, privacy, content usefulness, punctuality and billing are agreed by the experts, therefore these components are compatible to be matched under DART model. Mean score result for component perceived website innovativeness showed that the experts are partially agreed and considered the component as moderately compatible to be matched and included under dialogue.

Experts are partially agreed for perceived website innovativeness because this component is about customers' respond by giving innovative feedback to the company and even the definition mentioned about one side, this acts clearly shown the relationship between company and customer, so perceived website innovativeness is moderately compatible to be listed under dialogue [13, 33-34]. Based on Table 4, experts have disagreed for components valence and compensation, therefore these components are not compatible to be matched and listed under DART model.

Through the expert review, valence $[13,35]$ is not compatible to be listed under dialogue because this component was not directly showing the communication between company and customer but more to focus only towards customer impression. Valence is discarded to be listed under dialog because valence only involved customers' impressions that want to have good experience with the service compared to dialogue that insisted that both sides (company-customer) should interact with each other, therefore, it is shown clearly that there is no dialogue element in valence as it only involved one side and there is no interaction process happened [35-34]. 
Compensation [13,36] is not compatible because, in e-hailing, compensation does not guarantee to be given to the customer although the e-hailing apps have system failure, e-hailing company would suggest the customer to restart, reinstall the apps or only send the complaint to the customer service, therefore, compensation is not compatible to be included in e-hailing context.

There is no risk assessment element in compensation as risk assessment is about customers' willingness to deal and manage the risk which is clearly shown that the responsibility is on the customer alone as in this modern society, the company does not hold any responsibility that associate with risks [34]. Table 5 showed the definition of finalized matched components based on the expert review.

Table 4. Expert Review for Matched Component to be Listed under DART Model

\begin{tabular}{|c|c|c|c|c|}
\hline Factor & Matched Component & Mean Score & Level of Agreement & $\begin{array}{l}\text { Mean Interpretation for } \\
\text { Matched Component }\end{array}$ \\
\hline \multirow[t]{8}{*}{ Dialog } & Empathy & 4.67 & Agree & Compatible \\
\hline & Personalization & 5.00 & Agree & Compatible \\
\hline & Valence & 2.33 & Disagree & Not compatible \\
\hline & Responsiveness & 4.33 & Agree & Compatible \\
\hline & Communication & 5.00 & Agree & Compatible \\
\hline & Contact & 5.00 & Agree & Compatible \\
\hline & Interactivity & 5.00 & Agree & Compatible \\
\hline & Perceived website innovativeness & 3.67 & Partially Agree & Moderately Compatible \\
\hline \multirow[t]{7}{*}{ Access } & Tangible & 4.33 & Agree & Compatible \\
\hline & Ease of use & 5.00 & Agree & Compatible \\
\hline & Website design & 4.67 & Agree & Compatible \\
\hline & Information & 4.33 & Agree & Compatible \\
\hline & Content adequacy & 4.33 & Agree & Compatible \\
\hline & System availability & 4.67 & Agree & Compatible \\
\hline & Accessibility & 4.33 & Agree & Compatible \\
\hline Risk & Perceived risk & 4.67 & Agree & Compatible \\
\hline \multirow[t]{2}{*}{ assessment } & Perceived cognitive & 4.67 & Agree & Compatible \\
\hline & Compensation & 2.00 & Disagree & Not compatible \\
\hline \multirow[t]{8}{*}{ Transparency } & Assurance & 4.33 & Agree & Compatible \\
\hline & Trust & 4.67 & Agree & Compatible \\
\hline & Reliability & 4.00 & Agree & Compatible \\
\hline & Security & 4.33 & Agree & Compatible \\
\hline & Privacy & 4.33 & Agree & Compatible \\
\hline & Content usefulness & 4.67 & Agree & Compatible \\
\hline & Punctuality & 4.67 & Agree & Compatible \\
\hline & Billing & 4.33 & Agree & Compatible \\
\hline
\end{tabular}

These definitions are finalized and adjusted based on comments from the experts because expert's opinions can be used as the formal result [23]. Consequently, based on result and analysis from the expert review, the conceptual model is constructed as shown in Figure 2.

Table 5. Definition of Finalized Matched Components based on Expert Review

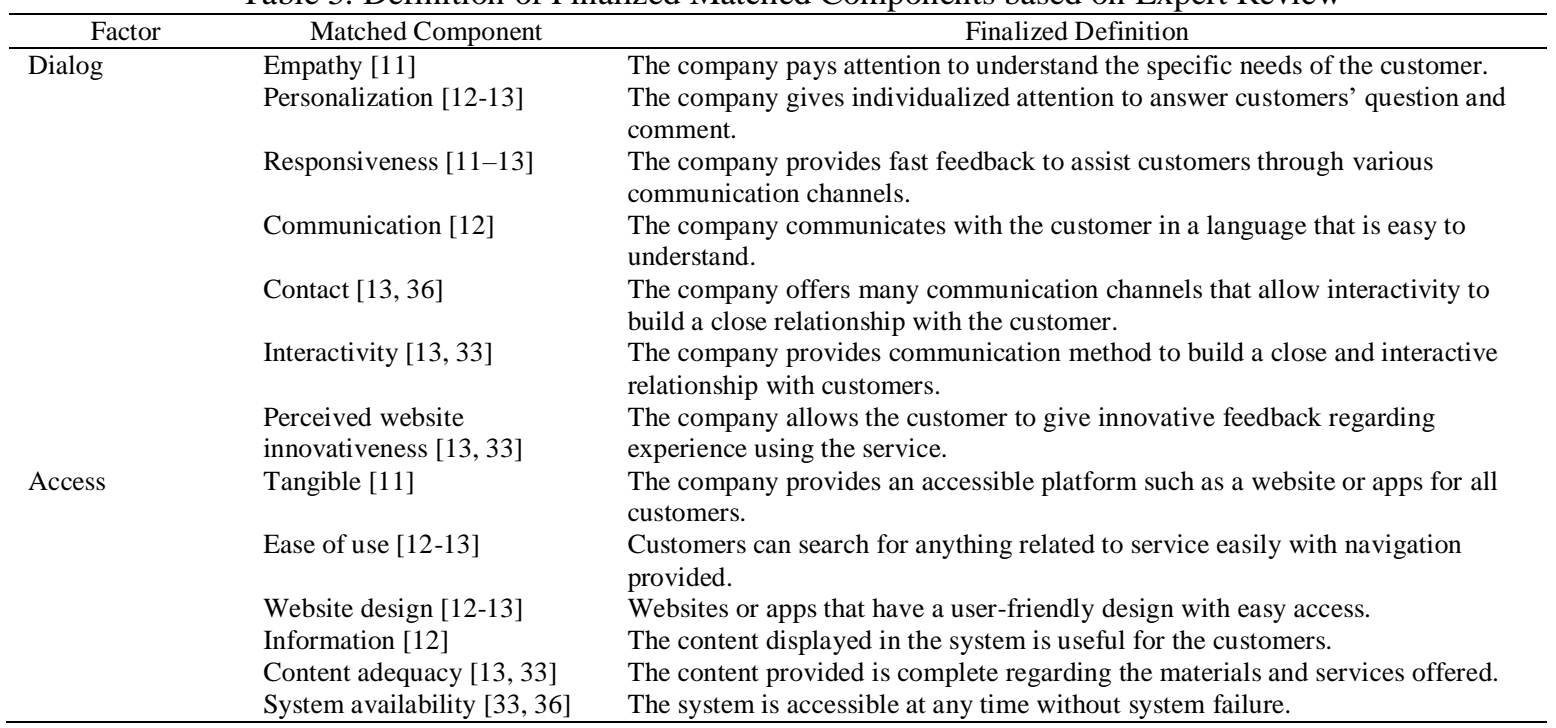




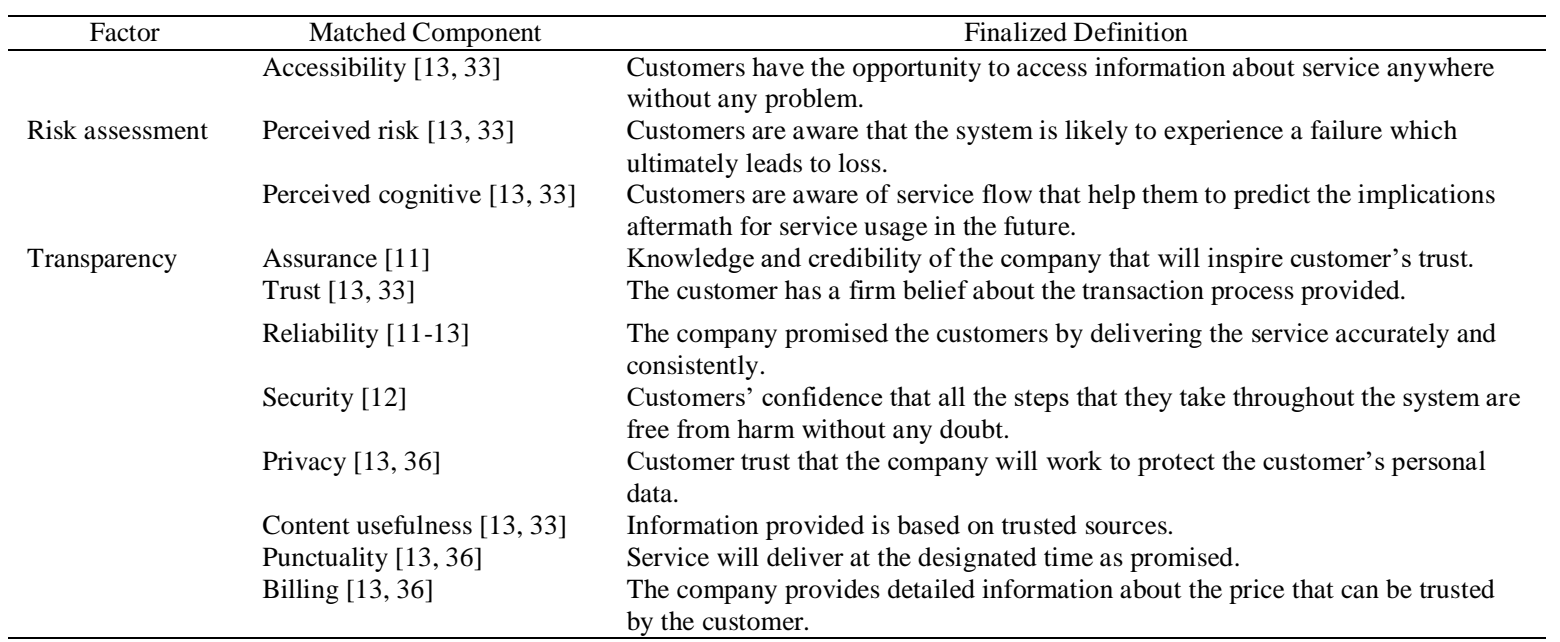

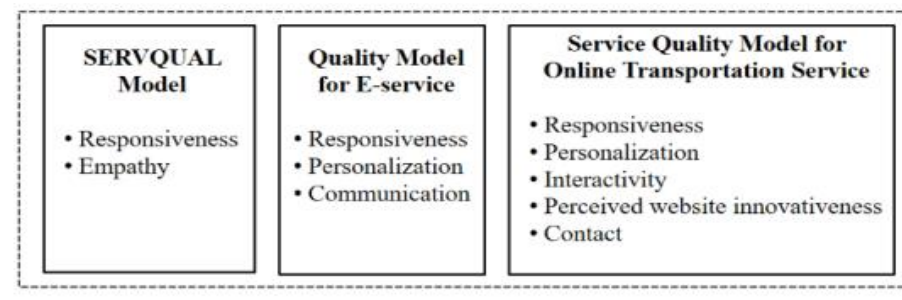

\begin{tabular}{|c|c|c|}
\hline $\begin{array}{l}\text { SERVQUAL } \\
\text { Model }\end{array}$ & $\begin{array}{l}\text { Quality Model for } \\
\text { E-service } \\
\text { - Ease of use } \\
\text { - Website design } \\
\text { - Information }\end{array}$ & $\begin{array}{l}\text { Service Quality Model for } \\
\text { Online Transportation Service } \\
\text { - Ease of use } \\
\text { - Website design } \\
\text { - Content adequacy } \\
\text { - System availability } \\
\text { - Accessibility }\end{array}$ \\
\hline
\end{tabular}
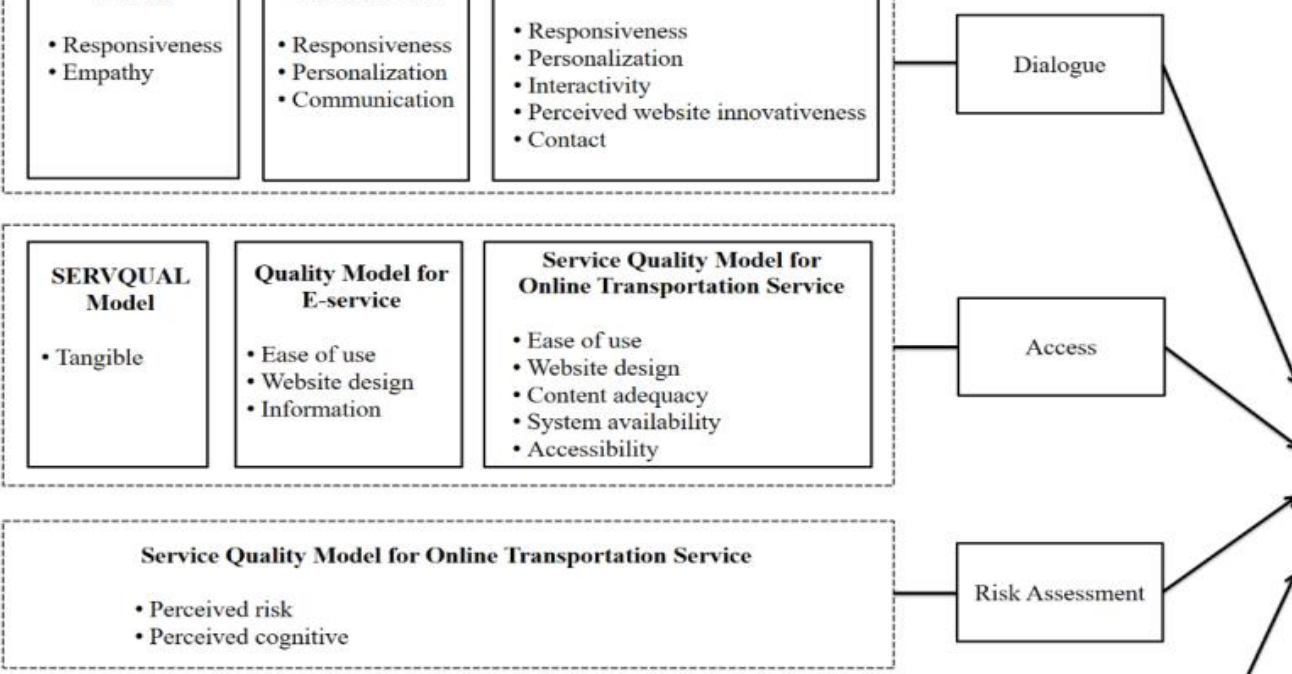

Customer Satisfaction towards E-hailing

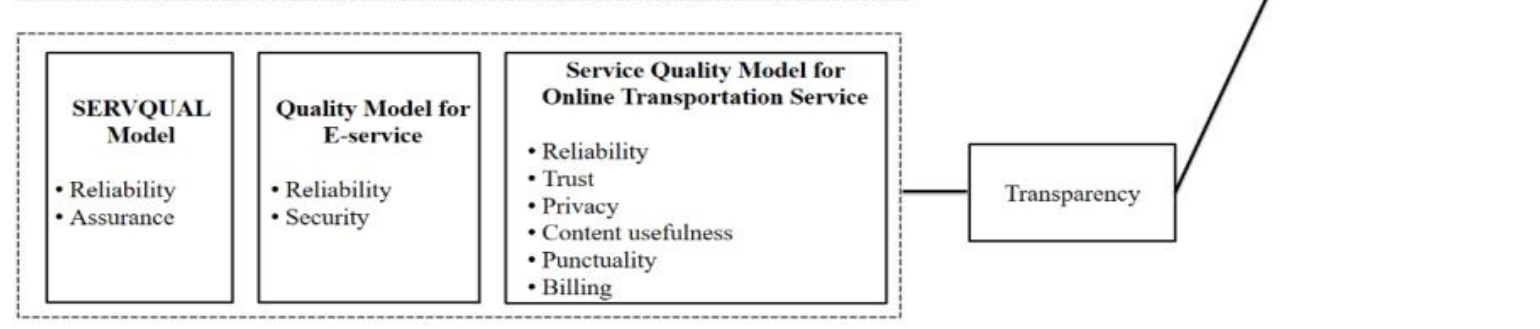

Figure 2. Customer Satisfaction Model towards E-hailing based on Expert Review

As discussed above, the customer satisfaction model towards e-hailing has used DART model as the main factor which consists of components from [11-13], are extracted, then, reviewed by the experts. All the components that are compatible to be listed under DART model have been finalized in Table 5 and visualized in Figure 2. Meanwhile, the components that are not compatible and discarded from DART model also have been discussed.

Thus, it is clearly shown that DART model conveys wide definitions, functions and able to own listed components. Further research about value co-creation in e-hailing is needed especially for improving customer satisfaction level as obtaining the satisfaction will interpret the level of comfort and acceptability towards the system [37]. Obtaining satisfaction from the customer is a benchmark to show that the service has achieved tremendous growth and success [38]. 
This study contributes to effective engagement between e-hailing customer and company as DART model emphasizes on the engagement platform. The engagement process requires the correct strategies to ensure the environment between all the users become interactive [39]. In the future, DART model should perform in quantitative studies and expected to give a significant impact on customer satisfaction towards e-hailing.

\section{CONCLUSION}

This paper proposed the adaption definition of DART model for e-hailing to be reviewed and justified by the experts. After that, the experts also play the role to validate and well-matched the components under DART model. Furthermore, this study showed the method to measure expert review such as by using the statement from the expert as the formal result and the mean approach as the calculation method. Ultimately, the study on the components that have been well-matched under DART model should be explored especially in quantitative studies. Further study on value co-creation concept towards e-hailing is recommended in the future as company-customer interaction nowadays is very important for the business growth. Thus, as a way forward, the future research involving value co-creation field should do more empirical studies such as by using survey approach.

\section{ACKNOWLEDGEMENTS}

This study is supported by Universiti Kebangsaan Malaysia through the Research Grant GGP-2017021 and Research Grant GUP-2017-099.

\section{REFERENCES}

[1] J. M. Vivoda, A. C. Harmon, G. M. Babulal, and B. J. Zikmund-Fisher, "E-hail (rideshare) knowledge, use, reliance, and future expectations among older adults," Transp. Res. Part F Traffic Psychol. Behav., vol. 55, pp. 426-434, 2018.

[2] S. Shaheen, N. Chan, and L. Rayle, "Ridesourcing' s Impact and Role in Urban Transportation," ACCESS Magazine, University of California, Berkeley, pp. 1-9, 2017.

[3] N. Stalmašeková, T. Genzorová, T. Čorejová, and L. Gašperová, "The Impact of Using the Digital Environment in Transport," in Procedia Engineering, 2017, vol. 192, pp. 231-236.

[4] I. Balachandran and I. Hamzah, "The Influence of Customer Satisfaction on Ride-Sharing Services in Malaysia," Int. J. Account. Bus. Manag., vol. 5, no. 2, pp. 184-196, 2017.

[5] C. R. Wang and M. Jeong, "What makes you choose Airbnb again? An examination of users' perceptions toward the website and their stay," Int. J. Hosp. Manag., vol. 4, 2018.

[6] C. Lorenzo-Romero, E. Constantinides, and L. A. Brünink, "Co-creation: Customer Integration in Social Media Based Product and Service Development," in Procedia - Social and Behavioral Sciences, 2014, vol. 148, pp. 383-396.

[7] M. Mukhtar, M. N. Ismail, and Y. Yahya, "A hierarchical classification of co-creation models and techniques to aid in product or service design," Comput. Ind., vol. 63, no. 4, pp. 289-297, 2012.

[8] National Association of City Transportation Officials, "Ride-hailing Services: Opportunities \& Challenges for Cities," New York, 2016.

[9] N. F. Elias, H. Mohamed, and R. R. Arridha, "A study on the factors affecting customer satisfaction in online airline services," Int. J. Bus. Inf. Syst., vol. 20, no. 3, p. 274, 2015.

[10] N. A. N. M. Idros, H. Mohamed, and R. Jenal, "Determinant Factors of Customer Satisfaction for E-hailing Service: A Preliminary Study," in Advances in Intelligent Systems and Computing, F. Saeed, N. Gazem, F. Mohammed, and A. Busalim, Eds. Springer, Cham, 2019, pp. 803-811.

[11] A. Parasuraman, V. A. Zeithaml, and L. L. Berry, "SERVQUAL: A Multiple-Item Scale for Measuring Consumer Perceptions of Service Quality," J. Retail., vol. 64, no. 1, pp. 12-40, 1988.

[12] J. Ojasalo, "E-Service Quality: A Conceptual Model," Int. J. Arts Sci., vol. 3, no. 7, pp. 127-143, 2010.

[13] S. L. B. Silalahi, P. W. Handayani, and Q. Munajat, "Service Quality Analysis for Online Transportation Services: Case Study of GO-JEK," in Procedia Computer Science, 2017, vol. 124, pp. 487-495.

[14] K. Xie, Y. Wu, J. Xiao, and Q. Hu, "Value co-creation between firms and customers: The role of big data-based cooperative assets," Inf. Manag., vol. 53, no. 8, pp. 1034-1048, 2016.

[15] H. Mohamed, N. F. Elias, M. Mukhtar, Y. Yahya, S. A. Hanawi, R. Jenal, and W. A. Z. W. Ahmad, "Model Nilai Cipta-Sama Dalam Sistem Pengukuran Prestasi,” J. Pengur., vol. 45, no. 2015, pp. 155-163, 2015.

[16] C. F. Chen and J. P. Wang, "Customer participation, value co-creation and customer loyalty - A case of airline online check-in system,” Comput. Human Behav., vol. 62, pp. 346-352, 2016.

[17] M. N. Ismail, Y. Yahya, and M. Mukhtar, "Nilai Cipta-Sama Sistem Pengurusan Pembelajaran," J. Teknol. (Sciences Eng., vol. 60, pp. 21-29, 2013. 
[18] A. A. Nunes, T. Galvão, and J. F. e Cunha, "Urban Public Transport Service Co-creation: Leveraging Passenger's Knowledge to Enhance Travel Experience," in Procedia - Social and Behavioral Sciences, 2014, vol. 111, pp. 577-585.

[19] C. K. Prahalad and V. Ramaswamy, "Co-creating unique value with customers," Strateg. Leadersh., vol. 32, no. 3, pp. 4-9, 2004.

[20] P. A. Albinsson, B. Y. Perera, and P. T. Sautter, "DART scale development: Diagnosing a firms readiness for strategic value co-creation," J. Mark. Theory Pract., vol. 24, no. 1, pp. 42-58, 2016.

[21] K. Solakis, J. C. Peña-Vinces, and J. M. Lopéz-Bonilla, "DART model from a customer's perspective: An exploratory study in the hospitality industry of Greece," Probl. Perspect. Manag., vol. 15, no. 2, pp. 536-548, 2017.

[22] Z. Zhang, Z. Zhang, and Y. Yang, "The power of expert identity: How website-recognized expert reviews influence travelers' online rating behavior," Tour. Manag., vol. 55, pp. 15-24, 2016.

[23] M. Ashcroft, R. Austin, K. Barnes, D. MacDonald, S. Makin, S. Morgan, R. Taylor, and P. Scolley, "Expert judgement," Br. Actuar. J., vol. 21, no. 2, pp. 314-363, 2016.

[24] D. Veen, D. Stoel, M. Zondervan-wijnenburg, and R. van de Schoot, "Proposal for a five-step method to elicit expert judgment," Front. Psychol., vol. 8, pp. 1-11, 2017.

[25] K. J. Mach, M. D. Mastrandrea, P. T. Freeman, and C. B. Field, "Unleashing expert judgment in assessment," Glob. Environ. Chang., vol. 44, pp. 1-14, 2017.

[26] P. J. R. De Jongh, J. Larney, E. Mare, G. W. van Vuuren, and T. Verster, "A proposed best practice model validation framework for banks," South African J. Econ. Manag. Sci., vol. 20, no. 1, pp. 1-15, 2017.

[27] S. Nisar and W. R. S. Osman, "BYOD Adoption Model Validation by Experts," Int. J. Comput. Sci. Manag. Stud., vol. 37, no. 1, pp. 1-6, 2017.

[28] K. Olson, "An examination of questionnaire evaluation by expert reviewers," Field methods, vol. 22, no. 4, pp. 295-318, 2010.

[29] M. N. A. Ghafar, Penyelidikan Pendidikan, Edisi Pert. Skudai, Johor Darul Ta'zim: Universiti Teknologi Malaysia, 1999.

[30] A. R. Colson and R. M. Cooke, "Expert elicitation: Using the classical model to validate experts' judgments," Rev. Environ. Econ. Policy, vol. 12, no. 1, pp. 113-132, 2018.

[31] W. Wiersma, Research methods in education : an introduction, 6th ed. Boston: Allyn and Bacon, 1995.

[32] W. A. Z. W. Ahmad, M. Mukhtar, and Y. Yahya, "Developing the Dimensions of a Social Content Management Framework," Int. J. Adv. Sci. Eng. Inf. Technol., vol. 8, no. 5, 2018.

[33] A. A. Salameh and S. Bin Hassan, "Measuring Service Quality in M-commerce Context : A Conceptual Model," Int. J. Sci. Reseach Publ., vol. 5, no. 3, 2015.

[34] O. B. Maduka, "Effects of Customer Value Co-Creation on Customer Loyalty in the Nigerian Service Industry," Int. J. Bus. Manag., vol. 11, no. 12, p. 77, 2016.

[35] E. Stiakakis and C. K. Georgiadis, "A Model to Identify the Dimensions of Mobile Service Quality," in 10th International Conference on Mobile Business, 2011, pp. 195-204.

[36] E. Y. Huang, S. W. Lin, and Y. C. Fan, "M-S-QUAL: Mobile service quality measurement," Electron. Commer. Res. Appl., vol. 14, no. 2, pp. 126-142, 2015.

[37] N. Abdullah and N. F. A. Hamid, "Interface design features of mobile application for senior citizens," Indones. J. Electr. Eng. Comput. Sci., vol. 14, no. 1, pp. 436-442, 2019.

[38] A. D. Poernomo and Suharjito, "Indonesian online travel agent sentiment analysis using machine learning methods," Indones. J. Electr. Eng. Comput. Sci., vol. 14, no. 1, pp. 117-122, 2019.

[39] N. H. N. Aziz, H. Haron, and A. F. Harun, "Components of Participatory Engagement within E-Learning Community,” Indones. J. Electr. Eng. Comput. Sci., vol. 12, no. 2, pp. 556-561, 2018.

\section{BIOGRAPHIES OF AUTHORS}

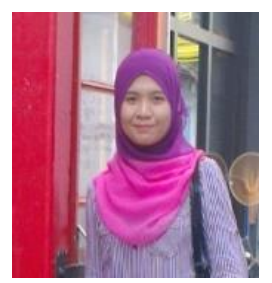

Nur Athirah Nabila Mohd Idros is a student of Faculty Information Science and Technology, majoring in Information Systems at National University of Malaysia (UKM), Malaysia since 2017 and is in the process of completing her master's degree. She holds a bachelor's degree in Information Technology from Universiti Tun Hussein Onn Malaysia. Her research interests are in service science particularly in topics related to measuring customer satisfaction.

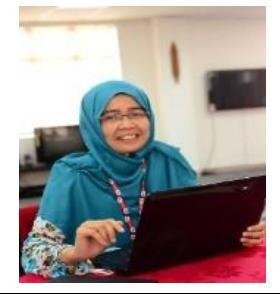

SmSn (UKM), SSn (UKMalaysia), PhD (UTM). Hazura Mohamed is a senior lecturer at the Center for Software Technology and Management, Faculty of Information Science and Technology, Universiti Kebangsaan Malaysia. Her field of expertise is service quality, exploratory data analysis and quality model. 
SmTM (UKMalaysia), MSc (Loughborough), PhD (UKMalaysia). Ruzzakiah Jenal is a lecturer ค at the Faculty of Information Science and Technology, Universiti Kebangsaan Malaysia. Besides teaching mathematics and statistics, her research interests are in the areas of mathematical modelling, scheduling and service science. Her field of expertise is mathematical modelling and scheduling. 